\title{
Investigating Chrematistics in Marketing Systems: A Research Framework
}

\author{
Djavlonbek Kadirov, ${ }^{1,2}$ Richard J. Varey, ${ }^{3}$ and Sally Wolfenden ${ }^{4}$
}

\begin{abstract}
Contributing to the analytical capacity of critical thinking in macromarketing, we develop a research framework that would enable researchers to investigate chrematistics in marketing systems. Chrematistics refers to regulative influences on marketing systems' structure and operations of market action perpetuated by actors with power/dominance. We outline the research framework consisting of a seven-step process that helps to scrutinize the transformative effect of chrematistic practices on the design and regulation of marketing systems.
\end{abstract}

\section{Keywords}

marketing systems, research methodology, chrematistics, marketing and society, capitalism, macromarketing

The true criticism of market society is not that it was based on economics - in a sense, every and any society must be based on it - but that its economy was based on self-interest. Such an organization of economic life is entirely unnatural, in the strictly empirical sense of exceptional (Polanyi 1944, p. 249).

...then as still, what is called sound economics is very often what mirrors the needs of the respectably affluent (Galbraith 1975, p. 86).

\section{Introduction}

Societal institutions shape not only marketing systems but also understandings thereof (Kilbourne 2004; Kilbourne, McDonagh, and Prothero 1997; Layton 2007, 2009; Layton and Grossbart 2006). The antecedent heterogeneity tradition in macromarketing recognizes the role of broader environmental conditions - specifically, formal, informal, and philosophical antecedents (e.g. institutions) - in the formation and development of marketing systems (Mittelstaedt, Kilbourne, and Mittelstaedt 2006). Since institutions are "the written and unwritten rules, norms and constraints that humans devise to reduce uncertainty and control their environment" (Ménard and Shirley 2005 , p. 1), representing society's conventionalized values and beliefs (Kilbourne, McDonagh, and Prothero 1997; Kilbourne et al. 2009), institutional variation across nations gives rise to a rich multiplicity of marketing systems with various levels of structural and functional complexity (Layton 2009). In macromarketing, the institutional foundations of societal and market relations are conceptualized and measured within the framework of the dominant social paradigm (DSP) that comprises several dimensions: economic, political, technological, organizational, and functional
(Kilbourne, McDonagh, and Prothero 1997). The DSP serves as an institutional framework through which people interpret observed reality. It can be influenced by, or designed to serve the interests of, dominant groups (Kilbourne, McDonagh, and Prothero 1997).

Deciphering the nature of institutional impact on markets is challenging, and even more so if investigations focus on how institutions influence research methodologies. Methodology refers to the reasoning, logic, and values that guide the design, selection, and use of specific research methods and techniques (Creswell 2012; Denzin and Lincoln 2011; Moses and Knutsen 2007). The choice and application of a particular method is essentially the function of the underlying methodology (Moses and Knutsen 2007). Methodology essentially refers to principles of inquiry, but in practice the ostensible practicalities of selecting and applying research techniques end up masking methodological assumptions in which these practicalities are embedded (Denzin and Lincoln 2011; Guba and Lincoln 2005). Consequently, the discussion of methodological principles must precede the development of a specific method geared to exploring marketing systems.

\footnotetext{
'School of Marketing and International Business, Victoria University of Wellington, Wellington, New Zealand

${ }^{2}$ School of Business, Eastern Institute of Technology, Napier, New Zealand ${ }^{3}$ Department of Marketing, University of Otago, Dunedin, New Zealand ${ }^{4}$ School of Tourism, Bournemouth University, Poole, UK

\section{Corresponding Author:}

Djavlonbek Kadirov, School of Marketing and International Business, PO Box 600 , Victoria University of Wellington, Wellington 6140, New Zealand.

Email: javlonbeck@gmail.com
} 
DSP-based methodological assumptions-namely methodological individualism, sterile market action, and nonexistent institutional influences - underscore the belief that the free-market mechanism and accompanying laissez-faire policies are superior to other market arrangements. Neoclassical thought highlights capitalism's expected societal benefits such as freedom and welfare (Sen 1993), whereas the latest defense of capitalism focuses on its links to personal virtues (McCloskey 2006). Accordingly, McCloskey argues that capitalism is defined as the advocacy for free markets largely driven by the middle class (i.e. the bourgeoisie) who are motivated by a holistic system of virtues including prudence (i.e. self-interest). This article challenges most of these assumptions, arguing that both accounts misrepresent the macro-character of market action that we label as chrematistics.

Chrematistics refers to regulative influences on a marketing system's structure and operations of market action perpetuated by actors with power/dominance. This definition might not be exactly what was meant by the term chrematistike when it was first offered by Aristotle, and then taken up by modern commentators (Crespo 2014; Daly and Cobb 1994; Dierksmeier and Pirson 2009). However, our definition is more general in that it accommodates the anecdotal cases offered by previous deliberations (e.g. greed-driven merchants manipulating people and governments). In addition, this definition allows for chrematistic tendencies that are positive, which other thinkers referred to as natural chrematistics or oikonomia (Crespo 2014; Daly and Cobb 1994). Hence, we admit that chrematistics can both serve and disserve marketing systems depending on its character of influence.

It is known that perfect "in-equilibrium" neoclassical markets are non-existent and that markets are almost always incomplete and inefficient (Hunt and Morgan 1995; Stiglitz 1991). There is always an opportunity to tweak the system (of exchanges) in such a way that it delivers what powerful classes desire (Polanyi 1944). What is considered to be the ideal state of the system (e.g. free markets) might in fact become corrupted with a specific latent disorder, and thus a methodology is needed to help scrutinize such conditions. There seems to be a need for a macromarketing methodology and a research framework that would allow macromarketing researchers to systematically investigate how chrematistics forms and evolves within marketing systems. So far, existing marketing systems research has dealt with how balanced marketing systems (should) operate (Kadirov and Varey 2011; Layton 2007, 2009). Perhaps it is now time to consider how chrematistics affects community-based systems and turns them into either soulless mechanisms of "output" generation, which are neither beneficial nor healthy for society at large, or genuine systems of community provisioning. Due to the limitations of scope and space here, we will focus mostly on the potentially negative aspects of the phenomenon.

We aim to develop both a critical methodology and an initial prescription for an analytical framework to address chrematistic tendencies in marketing systems. We first discuss and criticize methodologies related to mainstream economic thought on market systems. Next, based on the ensuing results of methodological discussion, we develop and outline a specific framework for inquiry that aims to scrutinize (negative) chrematistics. The proposed framework consists of a seven-step research process that guides researchers, practitioners, policymakers, and consumers in their efforts to understand and analyze markets from a critical perspective.

\section{Chrematistics}

Aristotle (2007) argues that the art of wealth-getting can be of two types: mistaken, negative chrematistics (i.e. commerce for the sake of wealth-accumulation), and natural chrematistics, which is subordinate to oikonomia (i.e. commerce that serves the purpose of good life within a household, community, or state). The former has no limits and is ever-growing, as it focuses on accumulating the tokens of wealth (e.g. coins, money), whereas the latter is limited by the needs of community (e.g. household) (Crespo 2014). It is striking how Aristotle alludes to the problematic nature of economic action with no limits. Aristotle notes that the pursuit of money as an end is irrational, whereas similar action as a means of attaining the good life within the polis (i.e. community, state) is acceptable. He also recognizes the necessity of wealth accumulation up to the point at which one can live liberally, while the pursuit of wealth beyond that point would be considered excessive. Accordingly, money (wealth) accumulation taken to such an extreme will alienate people from their community (Aristotle 2007; Crespo 2014; Daly and Cobb 1994; Dierksmeier and Pirson 2009).

Focusing on negative chrematistics, Aristotle (2007, part XI, paragraph 3) emphasizes its political aspect: "[the] device for getting wealth is of universal application, and is nothing but the creation of a monopoly. It is an art often practiced by cities when they are in want of money; they make a monopoly of provisions." He offers his generalized formula for chrematistic actions: to apply knowledge, skills, or authority (i.e. the sources of power) to monopolize the supply of particular goods/services. In the same vein, Daly and Cobb (1994) define chrematistics as "the branch of political economy relating to the manipulation of property and wealth so as to maximize [their] short-term monetary exchange value to the owner," whereas oikonomia (i.e. positive chrematistics) is defined as "the management of the household (community, systems, states), so as to increase its use value to all members of the household over the long run" (p. 138). These two modes of market action might not exist in their perfect/pure form in reality. The emphasis is on a balanced state of affairs where chrematistic tendencies should serve oikonomic purposes (Daly and Cobb, 1994; Dierksmeier and Pirson, 2009). The differences are depicted in Table 1.

To avoid conceptual confusion, we will follow Daly and Cobb (1994) and hereafter refer to positive chrematistics as oikonomia, while negative chrematistics will simply be referred to as chrematistics. The table depicts that the character of market action can be either opportunistic or benevolent. 
Table I. The Characterization of Chrematistics.

\begin{tabular}{lll}
\hline Dimensions & Chrematistics & Oikonomia \\
\hline Character & Opportunistic & Benevolent \\
Scope & Transactions & Communities \\
Concept of Value & Abstract exchange & Concrete use \\
\hline
\end{tabular}

Source: adapted from Daly and Cobb (1994).

Market systems are open scapes of provisioning (Fisk 1981), within which incumbent stakeholders are more interested in stable, just structures, but are often imperiled by "flyby-night" players flooding the market (Redmond 2013). In such cases, short-term priorities (e.g. quick money-making passions) clash with the long-term goals of market stability (Laczniak and Murphy 2012). Manipulative, opportunistic, and speculative action has no concern over the long-term health of markets (Redmond 2013; Varey 2010; Williamson 1985, 1993). An occurrence defined as a market inefficiency (to be taken advantage of in the short term) from the firm's point of view might be the very element that supports the market (Granovetter and Swedberg 1992; Redmond 2013). The second contrast is that of scope: the transactional concern must always be coupled with the systems concern. The focus on consumer satisfaction only, for instance, must not undermine the interests of stakeholders (Laczniak and Murphy 2006, 2012; Redmond 2009).

The third distinction, concept of value, is the key one. With regard to this, Aristotle (2007) says:

Of everything which we possess there are two uses: both belong to the thing as such, but not in the same manner, for one is the proper, and the other the improper or secondary use of it. For example, a shoe is used for wear, and is used for exchange; both are uses of the shoe. He who gives a shoe in exchange for money or food to him who wants one, does indeed use the shoe as a shoe, but this is not its proper or primary purpose, for a shoe is not made to be an object of barter (Part IX, paragraph 3).

This passage is perhaps the earliest account of the perspective of "value-in-use" (Ballantyne and Varey 2006). Aristotle considers the concrete use of a product/service to be primary. While in ideal settings (information symmetry, weak chrematistic influences, restrained opportunism) exchange value must approximately reflect the use value of resources, competitiveness and opportunism coupled with imperfect information and other tendencies (i.e. moral hazard) can obfuscate the link. For instance, the condition of imperfect, asymmetric information begs for solutions in both advanced and developing countries (Geertz 1978; Stiglitz 2002, 2010). Generally, the focus on generating increased exchange value entails commoditization, marketization, and commercialization (Brennan, Eagle, and Rice 2010; Heilbroner 1985; Patsiaouras, Saren, and Fitchett 2015), while the focus on use value tends to galvanize sensitivities related to sustainability, quality of life, equality, societal infrastructure, public goods and welfare systems (Galbraith 1958; Kadirov 2011; Kilbourne, McDonagh, and Prothero
1997; Varey 2010). Moreover, the meaning of "use value" can be reinterpreted from a macro perspective. Daly and Cobb (1994) emphasize the use value (i.e. benefits) of communitybased economy, and not just that of resources/goods. This insight is related to the macro aspect of markets, as it can be extended to issues related to the regulation (design, management) of marketing systems. We note that the use value of a marketing system in the sense of benefiting market participants and non-participants equally is an important notion. Markets benefit people in many ways. Market benefits include provisioning (Fisk 1967; Layton 2007), but also symbolism (Kadirov and Varey 2011), ideologies (Kilbourne, McDonagh, and Prothero 1997), identity construction, and the extension of self (Belk 1988), liberal life and welfare (Sen 1993; Stiglitz 1991), and morality (McCloskey 2006). Hence, we see chrematistics as market action that is political (enabled by power structures), and which influences the formation, design, and regulation of marketing systems. Chrematistics can be both positive (oikonomia), when it helps to increase the use value of the system for all stakeholders, and negative, when it transforms the marketing system into a predominantly exchangevalue (or money) retrieval "mechanism."

\section{A Neoclassical Solution to the Negative Impact of Chrematistics}

The formation, design, and regulation of marketing systems are on-going dynamic processes (Layton, 2007; Mittelstaedt, Kilbourne, and Mittelstaedt 2006). Markets are complex social constructions: i.e. agora, the product of human aspirations, actions, decisions, and power relations (Mittelstaedt, Kilbourne, and Mittelstaedt 2006; Polanyi 1944; Schwartz, 1986). The use of power that flows from one's privileged position and advantageous access to information or other resources can corrupt a marketing system in such a way that exchange value ends up significantly exceeding use value, which could diminish the use value of the whole system.

Aristotle (2007) sees chrematistics, the art of wealth-getting for the sake of accumulation, as the direct cause of monopolistic tendencies. While a sovereign uses power, a philosopher (and other entrepreneurs) uses practical knowledge, knowhow, and wisdom to create a localized monopoly and reduce the impact of competition. We must note here that Aristotle's discussion is a distant precursor of Chamberlin's theory of monopolistic competition (Chamberlin 1933; Hunt 2011).

The neoclassical school offers an elegant solution to the problem of negative chrematistics. Neoclassicists argue that if the design of markets ensures adequate competition by, for example, regulating or breaking up monopolies (whether natural, state-sanctioned, or private), then the pursuit of wealth, irrespective of whether it is self- or community oriented, must lead to positive outcomes (Hunt and Morgan 1995). Therefore, the free-market mechanism based on a great number of atomistic units pursuing "wealth-getting" was to be created. It is thought that the free-market mechanism guarantees use value and societal welfare, through a) promoting human freedom 
(linked to the ideas of political liberalism and libertarianism); and b) enabling economic growth, and by implication enhanced consumption (Kilbourne, McDonagh, and Prothero 1997; Kilbourne et al. 2009). However, both these points are contentious unless one is willing to apply DSP "lenses" and maintain that freedom equals the protection from state interference in the first case (Sen 1993), and that quality of life equals material consumption in the second one (Kadirov 2011; Kilbourne, McDonagh, and Prothero 1997).

Regarding the former, Sen (1993) shows that the ubiquitous reference to liberalism/freedom (e.g. libertarian rights) as a justification for free markets is mistaken, since the association between substantial freedom and the neoclassical conception of markets is contentious. Moreover, as Sen (1993) notes, only one aspect of freedom - "immunity from interference" - out of many other richer aspects tends to be narrowly emphasized in this respect. The next point, however, is less rhetorical. It comes in the form of the "welfarist" (or the Smithian view) theorem, which comprises two assumptions about the macroqualities of free markets: a) unrestricted competition leads to equilibrium that is Pareto-efficient (i.e. no one's utility can be improved without sacrificing someone else's utility); and b) the socially optimal result can only be achieved in the form of Pareto-efficiency given the initial (fair) redistribution of resources (Sen 1993; Stiglitz 1991). In other words, the freemarket system would simply redistribute resources among established market players (Sen calls them "the core") thus perpetuating the status quo, while its non-core welfare performance would largely depend on non-market mechanisms of resource allocation. The second element is paradoxical because it implies that optimal welfare can only be attained by effecting institutional arbitration that radically re-allocates resources. But such arbitration might require no less than a DSP-scale "revolution." Even more so, it might encourage monopolistic tendencies (Piketty 2014). Moreover, another key result is that although Pareto-efficiency does not necessarily guarantee social optimality, it is assumed that every socially optimal outcome has to be Pareto-efficient (Sen 1993). Hence, the final verdict of the theory is that only the market mechanism (in its autonomy) can ensure societal welfare. Consequently, citizens must simply leave the market to do its work (Stiglitz 1991).

The neoclassical methodology evolved into an ideological defense of complex capitalistic tendencies in society. It is based on several methodological assumptions. These include a) methodological individualism (Blaug 1980; Granovetter 1988; Kirchgässner 2014), b) socially sterile market action (Granovetter and Swedberg 1992), and c) inconsequentiality of institutions (North 1989). Methodological individualism is based on the principle that explanations of social and economic phenomena can only be adequate if they can be meaningfully linked/reduced to individual psychology (i.e. personal beliefs, motives, attitudes, behavior, and decisions) (Blaug 1980). This principle is essentially atomistic in its assumption of individuals who are free from relations with others, others' influence, and a history of relations (Granovetter 1988). The second assumption treats market action as a neutral, inert, sterile, isolated economic quest by applying the notion of rational maximization of self-interest to the general model of "homo economicus" (Kirchgässner 2014). Essentially, based on this principle it is possible to interpret any action as driven by self-interest once researchers settle for this mode of thinking (Gantt and Burton 2013; Sen 1977). The third assumption is based on the idea that the impact of institutions on economic action is negligible. As North $(1981$, p. 5) comments: “The world with which it [neoclassical formulation] is concerned is a frictionless one in which institutions do not exist and all change occurs through perfectly operating markets." These assumptions gradually become morphed into conventions and rules. Patterns in markets thus become more or less institutionalized (Granovetter and Swedberg 1992; Kilbourne et al. 1997; Polanyi 1944). Thus, ironically, the neoclassical formulation discounted the impact of institutions, such as "free markets," that it and all its assumptions helped to form.

\section{Chrematistics versus Disembeddedness}

Is chrematistics disembedded economic action? Disembeddedness refers to the degree to which market action becomes independent of non-economic institutions (Polanyi 1944). Polanyi argues that the limitless pursuit of wealth was less pronounced in ancient and pre-industrial markets because they were profoundly embedded in non-economic institutions (power structures, kinship relationships, social ties). He also shows that as capitalist economies developed, the communal nature of economic action has gradually weakened, while exchanges have become more driven by rational considerations, and have been freed from the constraints of social/kinship relationships. Polanyi observes that a general move toward disembeddedness is not a natural drift, but the result of purposeful regulative intrusion by dominant classes that introduces self-serving interpretations of so-called "free" mechanisms of markets. However, Polanyi recognizes that perfect disembeddedness is not possible, as society would always counter purely commerce-driven culture.

Granovetter $(1985,1988)$ disagrees with the above claims of the "substantialist" school, arguing that markets in both preand post-industrial ages are embedded in social relations, while the nature of such relations can be different. Granovetter also shows that economic action is always embedded in social structures (i.e. institutions).

\section{Society and Markets: Unity}

Action within a marketing system represents a type of social action at the same time, because of methodological inseparability between the "social" and "economic" (Arndt 1981; Granovetter and Swedberg 1992; Polanyi 1944; Varman and Costa 2008; Weber 1978). For instance, Max Weber (1978) convincingly argued that action (i.e. socio-economic behavior) takes its meaning from the system of collectively defined social meanings and that everything observed within the economy must be interpreted using these meanings. Moreover, he 
reasoned that neutral action is impossible, as any act (whether economic or other) must take others' behavior as a reference. At a more macro level, he saw economic action as a means of power struggle (Weber 1978). According to him, although markets operate freely, they are affected by different degrees of market power resulting largely from markets' internal dynamics.

The role of institutions in affecting how people interpret and practice marketing activities within marketing systems is indisputable (Arndt 1981; Berger and Luckmann 1966; Kilbourne, McDonagh, and Prothero 1997; Mittelstaedt, Kilbourne, and Mittelstaedt 2006; Varman and Costa 2008). The literature examines at length what institutions are and how they develop (Berger and Luckmann 1966; Granovetter and Swedberg 1992), but doing justice to this discussion is beyond the scope of this paper. We do emphasize here that institutions are not imposed externally. They arise as economic/social patterns that become "hardened" conventions within marketing systems as time passes (Berger and Luckmann 1966). Granovetter's (1988) thesis that market economies are always embedded in institutions that are continually being socially constructed is enlightening. In this vein, we argue that interactions within a marketing system, irrespective of whether they are chrematistic or oikonomic, will have a double character. On one hand, market activity (whether perceived to be neutral or negative/positive) will impact others and their market autonomy, while on the other such activity will have a regulative effect on market structure. The latter impact will greatly depend on market power. Hence, action is both operational and formative, in the sense that it enables actors to both operate in the market and influence its regulation. In relation to this issue, Weber (1978) reasons that market regulation can happen through a) historical tradition, b) social convention, c) law, and d) voluntary action. In some circumstances, the market can be assessed to be formally free, especially when law is successful in neutralizing restrictive traditions or conventions. However, the substantive regulation would still exist due to voluntary action by dominant groups who control resources and economic opportunities. Hence, if self-interest, atomism, and neutrality toward others' needs are taken to be the guiding values for action, then the patterns of social solutions for societal problems developed under these assumptions will crystallize as institutions (Kilbourne, McDonagh, and Prothero 1997), which in turn will have a regulative impact on a marketing system.

\section{Neo-Defense of Capitalism}

Another interesting justification for capitalism has recently emerged in the literature (McCloskey $(2006,2011)$. At the heart of McCloskey's resolute defense of modern capitalism is the thesis that capitalists (i.e. the bourgeois class, or the bourgeoisie) are in fact virtuous people whose industrious character commands the seven prominent virtues: prudence, love, courage, faith, hope, temperance, and justice. McCloskey goes on to attribute most achievements of modern times to capitalism, such as economic progress, innovation, abolishment of slavery, and the eight-hour working day, while arguing that these advances would not have happened had the bourgeoisie been driven by only self-interest or greed. McCloskey's (2006) stance is not simplistic; rather it is subtle and well-argued. She mounts a devastating critique of both the neoclassical schoolwhich, as she notes, celebrates "ruthless self-interest" - and its opponents who condemn the assumption. To become a good market player, one must both develop and practice the virtues in a balanced manner, she argues, pointing out that soundly operating markets not only presuppose morality, but also nourish it. However, except for a few examples related to interpersonal interactions in market settings, McCloskey does not offer a thorough explanation of exactly how this nourishment happens, although she promises to do so in subsequent volumes.

To pull off the difficult argument on bourgeois ethics, McCloskey $(2006,2011)$ commits three fundamental methodological dexterities. Firstly, capitalism is redefined as an advocacy for free markets, while capitalists are seen as "advocates for, and actors in, free markets" (McCloskey 2006, p. 86). This point is offered as a replacement for the Marxian conception of capitalism as "a boundless quest after riches," which has a negative connotation (Marx 1887, p. 80). We note that this line of argument is methodological individualism at work, which leads to methodological confusion about micro versus macro contexts. McCloskey's (2006) agenda is to explain the Great Fact, the macro phenomenon of manifold increases in wealth in Western countries, by attributing it to bourgeois morality, and also to the societal recognition of bourgeois moral superiority (McCloskey 2011). This approach leads her to see macro phenomena, including capitalism, in the light of micro conceptions. The Marxist view of capitalism is reduced to "greedy behavior," while the famous reference from Marx (1887) appears to be quoted out of context. Marx's theory is not that of individual psychology, but the observation of economic systems built on the transmogrification of use-value creation (the capital-money-capital cycles) into the exchange value maximization (the money-capital-money cycles). Moreover, Marx (1887) viewed capitalism as a historically established relationship between capital-owners and the working class. It is true that he attributed negativity to capitalism, but it was not because it represented capitalist greed. Rather, the critique was focused on the design of economic systems that ignored the plight of the working class, and was built on indifference toward extreme human suffering that occurred due to cyclical changes, recessions, industrial restructuring, and capital movements (Stewart 1984). Nevertheless, a neutral position is always possible. Capitalism is a macro phenomenon-it represents neither personal greed nor virtue, but rather it marks the epoch in which the leverage of market power granted by capital becomes possible (Polanyi 1944; Weber 1978). Such power can be leveraged to attain both favorable and unfavorable ends societally. What matters is a set of linked market institutions that normalize specific ends and means as meaningful, rational, and desirable (Granovetter and Swedberg 1992; Kilbourne, McDonagh, and Prothero 1997; Varey 2010). In the light of McCloskey's (2006) first assumption, the logical counter- 
question to ask would be whether the advocacy of free markets involves untying the hands of dominant classes to pursue what they see to be virtuous or, alternatively, substantial freedom that improves the market position of the destitute (Sen 1993).

Secondly, McCloskey (2006) recasts the bourgeoisie as the very broad middle class divided into three groups: la grande, or l'haute, bourgeoisie (very rich, owners of big wealth), the clerisy (intellectuals, the creative class), and la petite bourgeoisie (professionals, small business owners, workers). McCloskey assumes that the middle class is so "diluted" in Western countries that nearly all members of society can be classified as the bourgeoisie. However, she does not discuss the upper or lower classes to draw distinctions. Moreover, this assumption creates an interesting perspective on the critiques of capitalism. Since the criticism originates from the clerisy, who are part of the bourgeoisie, any work in this tradition is recast as "self-loathing." An interesting question arises here as to who constitutes the "other-than-middle" class implied by the study. The assumption that the bourgeoisie is the middle class can be countered by another question regarding what parties would have enough power and resources to be able to influence the design of markets (Layton 2007). The bourgeoisie are not everyone; neither are they the middle class (Bledstein and Johnston 2001; Wallerstein 1987, 2011). Even though bourgeois values may have become widely accepted, this does not imply that the number of the bourgeoisie has been exponentially growing. In fact, the macro-characteristic of capitalism is a growing income inequality that creates people with different levels of income, wealth, and by implication, market power (Piketty 2014). The bourgeoisie are the class of people who have sufficient resources, wealth, and market power to be able to influence market institutions, and thereby the design of marketing systems (Layton 2007; Redmond 2013; Wallerstein 1987, 2011). For example, Dholakia (2012, p. 8) is concerned about the excessive power of global financial institutions, which influences marketing:

In the marketing discipline, we need to come to grip with the fact that - especially in times of economic crises - not just consumers but also marketing managers become mere pawns in the Great Game of Finance, a game that has turned both global and reckless. The tilting concentration of power in the global financial center affects all aspects of economy, society and culture-including marketing practices, brands, and consumers.

Finally, McCloskey (2006) engages with the concept of prudence-as-virtue, and essentially redefines it as selfinterest. Therefore, self-interest is not a negative attribute, but one of the elements in the system of all virtues. In this vein, McCloskey reports her observation that in reality people, including the bourgeoisie, are never driven by prudence alone, but rather act on the balanced combination of all virtues. This assumption is also contentious, as the concept of prudenceas-virtue is distinct from what one might call the pursuit of selfinterest. Prudence is a type of practical wisdom that allows one to make correct choices in complex situations (Aquinas 1981).
Aquinas sees prudence as an intellectual ability that enables one to deeply understand morality, apply moral principles to specific situations, and in consequence, make sound choices. Accordingly, it is the "know-how" of attaining moral excellence. Aquinas also believes that within the system of virtues the pursuit of short-term passions tends to impede the soundness of judgments. Moreover, research shows that in some circumstances prudence would require one to commit to choices that might negatively affect self-interest (Etzioni 1988, 1999; Sen 1993).

From a macro perspective, however, systems are not the mechanical aggregation of their components. Even if one is willing to accept McCloskey's argument that the majority in the middle class is virtuous, this does not imply that marketing systems within which the middle class operates are equally "virtuous." What is needed is methodological sensitivity toward how conflicts between self-interest and other virtues are resolved, while some of these resolutions might become bases for institutions that have a regulatory effect on marketing systems. Drawing on the results of the methodological discussion given above, we next develop and outline a framework that consists of the seven-step process that focuses on investigating various effects of chrematistics in marketing systems.

\section{A Framework for Analyzing Chrematistics in Marketing Systems}

\section{Aims and Function of the Method}

The method for analyzing chrematistics in marketing systems aims to identify the extent to which marketing systems could possibly deviate from their oikonomic purposes: that is, provisioning communities and serving community welfare. The proposed research framework uses the chrematistics/oikonomia distinction as an investigative tool to shed light onto contemporary quandaries that arise at the interface between morality and markets. The framework's function is to help to surmount two analytical barriers when analyzing marketing systems. The first barrier is linked to the difficulty of analytically determining the boundaries of an affected system, while the second barrier is related to macro/micro sensitivity. Specifically, the first analytical barrier pertains to distinguishing the patterns of practice that allow particular market actors to capitalize on societal resources, in contrast to those institutions that are designed/perpetuated to serve communities (Dierksmeier and Pirson 2009; Polanyi 1944). Post-hoc analyses of market failures in identical industries or settings could be a good starting point (Redmond $2005,2009,2013)$. In perpetually operating marketing systems in which failures are not readily apparent, however, it might take extra effort, close engagement, and sharp inquisitiveness in investigating these systems. In such investigations, insiders knowledge - for example, that of whistleblowers - could be of great value. Moreover, historical analyses such as the studies of path-dependent development of institutions could unearth unexpected findings about taken-for-granted market structures (Acemoglu, Johnson, and Robinson 2006; Berger and 
Luckmann 1966). The second barrier is the researcher's capability of discerning self-interest-driven (micro) action from chrematistic (macro) action. While the former can be ubiquitous among most market-system actors, the latter is specific to powerful actors whose action could have a regulative effect on marketing systems. The current framework focuses on chrematistics at the systems level. Even though individual selfinterest, or even contrasting morality, might influence systems chrematistics, general societal outcomes (e.g. welfare and standard of life) will depend on the extent to which chrematistic tendencies are institutionalized.

\section{Focus and Motivation}

The method focuses on phenomena that might be indiscernible from an individual perspective, in particular, when one takes methodological individualism as a guiding principle. Systems chrematistics can become normalized in a marketing system to the extent that most market actors would not be able to "see" it due to DSP-related effects. Most people live virtuous lives (McCloskey, 2006) and detest vices in everyday social interactions. "Self-interest seeking with guile" stirs moral detestation (Williamson 1985), and is a fundamental notion in the theory of "non-neoclassical" marketing (Hunt and Morgan 1995). Nevertheless, when focusing on what is immediate, most people might fail to see the forest for the trees. Honest and hardworking people could end up contributing to the chrematistics of marketing systems because of their systems-blindness. Observing such a paradox in the context of the recent financial crisis, Stiglitz (2010, p. xxiv) wrote:

I criticize - some might say, vilify - the banks and the bankers and others in the financial market. I have many, many friends in that sector-intelligent, dedicated men and women, good citizens who think carefully about how to contribute to a society that has rewarded them so amply. They not only give generously but also work hard for the causes they believe in... As seems to happen so often in our modern complex society, "stuff happens". There are bad outcomes that are the fault of no single individual. But this crisis was the result of actions, decisions, and arguments by those in the financial sector. The system that failed so miserably didn't just happen. It was created. Indeed, many worked hard-and spent good money-to ensure that it took the shape that it did.

However, the big picture is never completely hidden. In fact, the protagonists of the regulative influence (i.e. chrematistics) do not lack such knowledge. Morgenson and Rosner (2011) refer to a number of influential actors (whom they call selfinterested, politically influential, and arrogant) both in the government and private sectors who contributed to the design of the market system that led many astray.

\section{Summary of the Proposed Investigative Model}

Figure 1 presents the general view of the main steps involved in the analysis of chrematistics. The model consists of the seven steps, where some steps (1 and 3 ) have several sub-steps. The

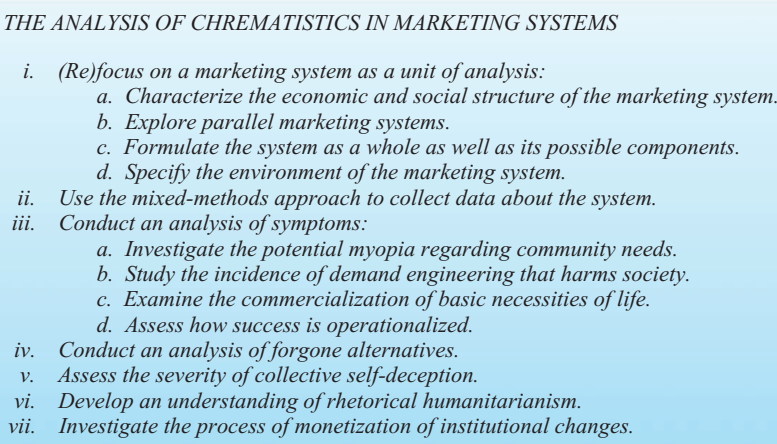

Figure I. Steps in the analysis of chrematistics in marketing systems.

proposed model is certainly not the final word on the subject matter. Instead, we consider this as initial groundwork that must be re-tested through rigorous field observation.

\section{Research Process}

\section{(Re)Focusing on a Marketing System as a Unit of Analysis}

Perhaps the most challenging task for the researcher will be to transcend a micro-managerial context of an enterprise and adopt a broader view of marketing when identifying the unit of analysis. Hence, the initial step in the research process is to attempt to refocus the research project at hand from the study of an individual firm or consumers to the exploration of a marketing system (Layton and Grossbart 2006). The following definition of a marketing system can be accepted as a guide:

[...] a network of individuals, groups, and/or entities, linked directly or indirectly through sequential or shared participation in voluntary exchange, which jointly creates, assembles, transforms, and makes available assortments of products, services, experiences, and ideas, provided in response to customer demand (Layton 2007, p. 230).

Researchers should realize that an individual exchange or a market act does not stand in isolation - it is only meaningful within the structure of a whole (a complex system of market interactions, interdependencies, and relationships). They might decide to go even further and conceptualize a system of marketing systems. For example, a particular exchange can be studied as a part of symbolic (i.e. meaningful) differentiation whereby new marketing systems emerge and develop in reference to the established ones (Kadirov and Varey 2011).

\section{Using the Mixed Methods Approach to Collect Data and Evidence}

In general, research questions and related methodological understandings should guide the choice of a research method. A researcher can employ different techniques ranging from direct observation, through personal experience, to viewing and 
interpreting visual materials and cultural texts. The analysis of text retrieved from corporate reports, websites, and other relevant publications using dedicated software is one such possibility (Loughran and McDonald 2011; Loughran, McDonald, and Yun 2009). For example, Humphreys (2010) analyzed the content of newspaper articles, press releases, legal precedents, written industry histories, and biographies to investigate the casino gambling industry and its formation as a legitimate marketing system.

Observation in daily experience and criteria-based assessment can be used to researchers' advantage. They can observe speech and actions that exhibit chrematistic intentions and impact on system conditions, while making use of scientific methods of content analyses. Some phenomena are more easily accessible and observable than others. For instance, neoclassical presumptions expressed as truths - growth, trickle-down of benefits, equating prosperity and happiness with wealth accumulation, fairness and efficiency of the supposed free market, competition and flaky ethics expressed as "just doing business" and "dog eat dog" — can be further scrutinized. The occurrences of insincere market behaviors, such as overpromising, bad faith, standardization (dumbing down), upselling, half-truths, mendacity, engineered choices, customers as "legal prey," and top-of-the-pyramid discrimination, might offer a good starting point.

\section{Conducting an Analysis of Symptoms}

A quick glimpse at the relevant literature attests to the fact that in most cases researchers realize the negative impact of chrematistics on society ex post facto (Daly and Cobb 1994; Dierksmeier and Pirson 2009; Stewart 1984; Stiglitz 2010). Analytically, telling from the onset that a particular situation is going to develop into a full-blown economic and societal crisis is very difficult. However, several symptoms of chrematistics might inform the researcher about the extent of chrematistic tendencies.

Investigating the potential myopia with regard to community needs. To discern patterns pertaining to chrematistics researchers should analyze how customer and other market actor needs are being interpreted within the system. In fact, the question of needs relates to the output of a marketing system. Is the output balanced in such a way that all parties and stakeholders more or less equally benefit from it in the long run (Laczniak and Murphy 2008, 2012)? Do the needs/demands of some actors (e.g. corporations, financial institutions) come to dominate those of others within the system? It would also be interesting to see if some market actors' long-run sustainable advantage strategies are in fact based on impeding other actors' long-term interests (Galbraith 1958; Kadirov 2011). For example, Lewis (2011) provides an interesting investigation of ethno-passions in several European nations that were fuelled by the availability of cheap credit and the impact of these tendencies on the general structure and functioning of marketing systems. In addition, researchers could study income and wealth inequality in society (Piketty 2014). A particularly useful approach is to study and compare the trends of the Gini coefficient of income, wealth, and opportunity.

Another case in point is the U.S. housing crisis, where the demand for housing became interpreted and responded to as an investment vehicle (Redmond 2013; Stiglitz 2010). The ideology of home ownership rooted in the American dream creates stable demand for houses (Redmond 2012), which is perhaps the key institution nurtured within the marketing system to reduce uncertainty (Ménard and Shirley 2005). Such stability could also become a means of risk reduction that investors desire. Consequently, macro changes resulted in loan contracts being transformed into securities that created a significant gap between the use and exchange value of houses. The impact on the design of mortgage offerings of the "exchange" mindset is Stiglitz's (2010, pp. 4-5) focus in the following passage:

In all these go-go years of cheap money, Wall Street did not come up with a good mortgage product. A good mortgage product would have low transaction costs and low interest rates and would have helped people manage the risk of homeownership, including protection in the event their house loses value or borrowers lose their job. Homeowners also want monthly payments that are predictable, that don't shoot up without warning, and that don't have hidden costs. The U.S. financial markets didn't look to construct these better products, even though they are in use in other countries. Instead, Wall Street firms, focused on maximizing their returns, came up with mortgages that had high transaction costs and variable interest rates with payments that could suddenly spike, but with no protection against the risk of a loss in home value or the risk of job loss ... Had the designers of these mortgages focused on the ends-what we actually wanted from our mortgage market - rather than on how to maximize their revenues, then they might have devised products that would have permanently increased homeownership. They could have "done well by doing good." Instead their efforts produced a whole range of complicated mortgages that made them a lot of money in the short run, and led to a slight temporary increase in homeownership, but at great cost to society as a whole.

Stiglitz (2010) notes that it was a type of modern alchemy, classic chrematistics, whereby the whole system became dominated by some actors' needs to repackage mortgages (which most often were subprime) into AAA-rated securities. This led to failures in the system with regard to performing its core functions: facilitating transactions, assessing risks, and making safe loans.

On the other hand, some observers note that the main culprit of the crisis was the political ambitions of some individuals with power who promoted unhealthy government intrusion that was heedless of the real needs of market actors (Morgenson and Rosner 2011). In any case, in conducting the analysis the researcher must go beyond the blame game (Redmond 2013; Stiglitz 2010). The focus must be on how individual players reacted to changes happening at the macro level. It seems that in the case of the U.S. housing crisis, local decisions by many parties (customer, banks, mortgage brokers, investment 
institutions, government agencies, politicians, rating agencies) worked in accord with anticipated/occurring changes that had a profound impact on the system's design (Redmond 2013). Powerful actors - for instance, Fannie Mae's chief executive and other politicians - had a role to play. However, what matters from the institutional perspective is how fast the predatory tactics become institutionalized as industrial norms due to the imitative work of other players (Morgenson and Rosner 2011).

Studying the incidence of demand engineering. The researcher will need to study whether there exists increasing effort to influence society/culture with a view to artificially expanding the demand for particular offerings when it is known that the expansion can be harmful for society at large in the long term. Back to the case of the U.S. housing market crisis: the mortgage market dominated the housing market, whereas subprime mortgages became a tool of artificial demand stimulation (Redmond 2013). Putting this metaphorically, "The tail did wag the dog" (Redmond 2013, p. 125). Consumer advocacy and sincere dedication to consumer interests is the hallmark of marketing ideology (Gaski 2012; Urban 2005). The marketing discipline emphasizes the marketer's neutrality - marketing should simply respond to the given demand of the masses (Gaski 2012). Layton (2007) sees the function of a marketing system as the supply of assortments of products/services in response to customer demand. Hence, in contexts where demand expansion could harm society (or a majority of stakeholders), the existing demand must be allowed to drive marketing activities rather than vice versa (Galbraith, 2004). Off-label marketing - promoting drugs to other-than-approved patients, a practice often employed by major pharmaceuticals - is an example of such synthetic market expansion (Kesselheim, Mello, and Studdert 2011). In the same vein, recent research shows that the U.S. gambling industry uses "megamarketing" techniques to effect gradual society-wide legitimization and general acceptance of casino gambling (Humphreys 2010). Similarly, the tobacco industry appears to be spending more on grooming the younger generation than advertising to adults, as the industry believes that new smokers can only be recruited from among teenagers (Hastings and Sheron 2013). Credit card companies are found to encourage bad debts (Henry, Garbarino, and Voola 2013), while goods manufacturers promote the "throw-away ethic" via the use of planned obsolescence (Bulow 1986; Slade 2009; Waldman 1993).

Examining the commercialization of the basic necessities of life. The researcher will need to examine how commercialization, marketization and globalization processes within marketing systems could affect human rights to basic necessities. The supply of currency, healthcare, utilities, education, staple food, and other infrastructural services are too important to be left at the mercy of chrematistic interests. Government subsidization of necessities could lead to situations when use value exceeds exchange value considerably; whereas commercialization might create the reverse situation. Marketization could have either a positive or a negative effect depending on how the process is managed, especially in developing economies (Kilbourne 2004; Stiglitz 2002). Kilbourne (2004) instructs that quality of life, environment, and substantive freedoms, prior to and after commercialization processes, should be carefully monitored in order to reach a better understanding of the situation. Many things can go wrong if transition is not managed for the benefit of all. A case in point is oligarchic capitalism developed in the republics of the former Soviet Union, whereby regulatory changes allowed the development of unbalanced, "free-market-like," imitative structures that in reality ended up monopolizing the supply of life necessities. The fusion of political power and wealth may work to deform marketing systems. The developed economies face the same danger, as Piketty (2014, p. 514) notes, that "the risk of a drift towards oligarchy is real and gives little reason for optimism about where the United States is headed." In fact, it is known that regulation creates markets and, paradoxically, it takes more regulation to enforce deregulation (Polanyi 1944). The researcher should gradually develop sensitivity to such issues. Another useful approach is to investigate parallel systems that satisfy the same need or demand (Layton 2007). Do parallel systems exist? Have they been deformed? Have they acquired the status of "illegal" or "black" due to current policy changes? And if so, why?

We maintain that balanced systems combining both public and private inputs need to be developed, taking into account national circumstances, culture, and traditions (Kilbourne 2004). Chrematistics might corrupt both public and private systems. In public systems, chrematistics leads to widespread corruption, to the extent that corruption becomes the only way the public supply systems can operate. In some instances corruption becomes so entangled with culture that analysts might wrongly assume that a particular culture might be fundamentally chrematistic in itself. Researchers might find it valuable to scrutinize the Corruption Perceptions Index and related case studies published by Transparency International to identify likely development paths for emerging market systems.

Privatization is certainly not a silver bullet, as the risk of chrematistics would still exist. If the service is of adequate quality and the rates are fair (i.e. when they do not deny low-income people the adequate access to basic services of acceptable quality), then there should be no issue with private companies supplying public services. However, as is often the case with developing countries, deregulation, privatization, and liberalization processes are managed for the benefit of the elite. The classic example of how corporate monopolization of life necessities can go wrong is the Cochabamba Water Protests. In 1999 the Bolivian government signed a deal with the consortium Aguas del Tunari that involved Bechtel (USA) and United Utilities (UK) as major partners to supply water and sanitation services to the residents of the Bolivia's third-largest city, Cochabamba. The government also passed Law 2029, giving the consortium rights over almost all water resources in the area. Aguas del Tunari started acting as a pure profitmaximizing monopoly. It confiscated independent communal water systems, started installing water meters on these systems, 
put the rates up by $35 \%$, and even banned rainwater collection from rooftops (this was perhaps a parallel system of provisioning).

For specific marketing systems, researchers can also measure and study the Herfindahl-Hirschman Index, the indicator of industry concentration. The growing index would indicate that the market power of some players is increasing at the expense of competition.

Assessing the operationalization of success. From a normative standpoint, researchers argue that the fundamental precept is that "the marketing system should always be of service to people," and that the dictum "people first" must always be implemented, at least in the long run (Laczniak and Murphy 2006, p. 157). A perturbing trend is that chrematistic systems are geared to maximizing a number of different factors. Most often the necessity for growth is exaggerated (Varey 2010). Discussing narrow metrics, Hill and Martin (2013, p. 18) note that

$[\ldots]$ as a result of the narrow and distilled thinking, marketing researchers ignore people's heterogeneity in favor of simplistic ways of operationalizing success. As a case in point, consider common performance metrics such as market share, gross sales, and return on investment. These metrics show little, if any, concern for contribution to the wellbeing of the people and communities that are significantly affected by what marketers say and do. This focus is akin to college football combines, in which players from around the country bench press a certain weight as many times as possible and run a sprint as fast as possible, signaling their athletic prowess without ever performing the skill set necessary to win games. Such metrics take on a life of their own and are used internally and externally to reward or punish employees, raise or lower stock prices, launch or remove products from the market, and open or close plants and distribution centers, all without much deliberation on their effects on the people involved.

Following Kant's moral philosophy, Laczniak and Murphy (2006) postulate that the humanity of people must never be used merely as a means to variously motivated ends. Some might argue that sacrifices (harming stakeholders, polluting the environment, employee lay-offs) are unavoidable or necessary to keep systems afloat. It is also wrongly assumed that the metrics at least serve the majority at the expense of the minority whose needs must be sacrificed (the necessary evil). However, such reasoning is misleading due to the fact that economic welfare does not exactly equate to human welfare (Kadirov 2011). Human welfare is a more holistic measure, while economic measures (e.g. GDP, income per capita, corporate profit) are simply reductionist.

\section{Conducting an Analysis of Forgone Alternatives}

The observable status quo in a marketing system is the consequence of a particular chain of previous decisions, commitments, and efforts that may have emphasized certain ends over others. Studies that focus on path-dependent development can help to analyze this aspect of marketing systems
(Acemoglu, Johnson, and Robinson 2006; Berger and Luckmann 1966). Researchers should focus not only on what has been achieved in a marketing system, but also on forgone possibilities. The pursuit of power and advantage within a marketing system has its opportunity cost- the communally beneficial ends-which could have been pursued instead. Researchers do ponder societally beneficial alternatives to the profit-maximization approach (Hill and Martin 2013; Sheth and Sisodia 2006; Varey 2010). Dierksmeier and Pirson $(2009$, p. 422) call for "a concrete analysis of the forgone alternative uses of one's time and energy" to investigate if any increase in wealth is truly constructive. Such an analysis could be pursued through the use of different research strategies. The researcher can initially conduct exploratory research to identify the nature and types of resources that have been diverted to serve the chrematistic end. Also, the next-best alternatives for action and welfare generation can be identified. Another possibility is to apply existing modeling tools to estimate resource elasticity of both the system-wide profit and holistically measured welfare.

\section{Assessing the Severity of Collective Self-deception}

Collective self-deception refers to groups' (e.g. system participants') false beliefs or hopes thoroughly perpetuated/construed in the face of evidence to the contrary (Baumeister and Hastings 1997; Gilbert 2005). Researchers can inquire about possible collective self-deception in markets in the face of known imminent economic perils. The analysis of the possible "tragedy of the commons" situations would be beneficial (de Coverly et al. 2008; Shultz and Holbrook 1999). The study by de Coverly et al. (2008) sheds light into socialization mechanisms through which waste is rendered invisible. Similarly, Lewis (2011) observes how traditional mindsets in Iceland, Ireland, Greece, and Germany have undergone dramatic changes because of the availability of easily accessible international credit. For instance, many Icelanders gave up traditional fishing-related occupations and self-deceptively thought that they possessed enough expertise to engage with investment banking (Durrenberger and Palsson 2015).

Specifically, the recognition of the chrematistic problem requires taking the macro perspective. Chrematistics involves dismissing the macro picture as irrelevant - in some cases it is considered to be the other people's or government's concern (see Gaski 2012) - and focusing on "the now." Back to the example of the U.S. financial crisis, post-hoc investigations showed that individual actors largely dismissed the macro view, despite a large number of warnings from different sources (Lewis 2010; Morgenson and Rosner 2011). At the transactional level, the market was doing what it was supposed to do, and nothing seemed to be wrong, as everyone was (seemingly) making profit. Mortgage agents pushed mortgage contracts to broader markets; the banks re-packaged these mortgages into securities; the financial institutions sold these securities to investors; and the rating agencies approved these securities, while the government agencies pursued political ambitions 
exploiting the national perceptions of the American dream (Morgenson and Rosner 2011; Redmond 2013; Stiglitz 2010). However, various experts and institutions issued multiple clear warnings. Most actors knew that something was systemically wrong in these individual transactions all taken together, but preferred to maintain collective silence about the possibility of financial meltdown (Lewis 2010; Heinberg 2011).

\section{Developing an Understanding of Rhetorical Humanitarianism}

Some societies (and their marketing systems) claim to focus on humanitarianism. However, such claims are mostly rhetorical in a sense that they are so abstract that a real connection with real people is lost in the process. For instance, it would be wrong to assume that socialist or communist systems (or any other alternative market formations based on uniformly imposed ideals) are less chrematistic. On the contrary, they possibly could become chrematistic to the bone. Lessons from the historical experiments with central-command market systems in the Soviet Union are not yet forgotten. Soviet leaders (and some current dictators) simply treated their countries as huge enterprises. All kind of resources, including tens of millions of human lives (not to mention the natural environment), were sacrificed at the altar of five-year plans. These systems were capable of an immense output, although most of it was of substandard quality, or even useless. Central command systems were simply the product of grand symbolic differentiation ("grand show" experiments), that were outwardly oriented, as entities distinct from those despised "capitalist" systems. The plight of ordinary folk, paradoxically, was of no concern. Interestingly, chrematistics might be one of those common features that unites the dehumanized brutality of communist systems and the profit-driven "entrepreneurism" of the West. A case in point is Foxconn, the electronics manufacturer that produces for well-known corporations including Apple, Microsoft, Samsung, and Sony. Foxconn tends to exhibit chrematistic ingenuity-perhaps the evil type-in co-opting the accumulated experience of mass labor organization, and running factories with labor-camp-like conditions (BBC 2012). The working and living conditions, which to some extent resemble battery-caged hen factories, are so abhorrent that employees have committed suicide by jumping off factory buildings. The company was found to have been installing netting around buildings to discourage suicide attempts (The Telegraph 2012).

\section{Investigating the Process of Monetization of Institutional Changes}

Last but not least, research could focus on situations whereby the structure of a marketing system undergoes significant changes to the benefit of parties that co-opt the support of powerful public agencies. Researchers study the negative effects of crony capitalism, unhealthy cooperation between state agencies and private businesses that allows the latter to exclusively access both economic and non-economic privileges denied to other market actors (Kang 2002). The crony-capitalism index published by The Economist offers a good starting point for such research.

Another case in point is that of statins and the fear of heart disease. Statins are drugs that reduce levels of cholesterol, a proven contributor to heart disease. In 1999, Lipitor was one of the many drugs in the marketplace that manufacturers, in this case Pfizer, wanted to feature. Due to regulations they were unable to state, "Lipitor prevents heart attacks," so they focused on the message that Lipitor was the best at lowering cholesterol. Pfizer needed one simple item of interest for their consumer to remember, and that emerged as "knowing your number," one's cholesterol level. The U.S. National Institute of Health (NIH) lowered the threshold at which cholesterol was considered too high and, as a consequence, overnight the number at risk (as a result of the change) went from 13 to 36 million. The premise here was that the more people who took statins, the better off society would be. Pfizer had financial ties to six of the committee members of the NIH (Burnett 2014).

\section{Concluding Comments}

Mick (2007 p. 291) states that one needs to see "marketing systems as a complex set of multi-layered, near-and-far relationships in which the choices and actions of market participants have long-term consequences beyond their firms, partners and customers." In this vein, we see chrematistics as the (intentional/unintentional) regulative influence of market actors with power, wealth, and dominance on the structure and operation of marketing systems. The design of marketing systems must account for such effects, as freedom granted by governments to market actors in the form of immunity from interference may not translate into effective (substantive) freedom for all. Specifically, chrematistics shows its "ugly head" when powerful market actors utilize their "freedom" to curtail the freedom of other actors. Although we mostly consider the negative consequences of such intrusions in this article, we maintain that positive outcomes are also possible. This insight could serve as a potential topic for future research.

In this article, we outline a general framework for detecting and gaining insight into chrematistics and its effects in marketing systems. This may have several uses. For scholars of business and economics, findings can explain and substantiate the basis for critiques of marketized society, consumerism, over-consumption, and outmoded capitalist economics. Researchers serving the interests of marketing management may find the method helpful as a systematic treatment of marketing effects that describes practices that do not live up to the spirit of the marketing concept in serving the needs of citizens. Policymakers may find substantiation of changes to marketing-related policy and regulations, and citizens can be sensitized to the findings of such investigations to assist them in understanding options in response to their marketing experiences. 


\section{Acknowledgments}

The authors thank the special issue editor Ben Wooliscroft, the editor Terrence Witkowski, and the three anonymous reviewers for their constructive feedback.

\section{Declaration of Conflicting Interests}

The author(s) declared no potential conflicts of interest with respect to the research, authorship, and/or publication of this article.

\section{Funding}

The author(s) received no financial support for the research, authorship, and/or publication of this article.

\section{References}

Acemoglu, Daron, Simon Johnson, and James A. Robinson (2006), "Institutions as the Fundamental Causes of Long-Run Growth," in Handbook of Economic Growth, Philippe Aghion and Steven Durlauf, eds. Amsterdam: Elsevier, 385-464.

Aristotle (2007), Politics, translated by Benjamin Jowett. Adelaide: eBooks.

Aquinas, Thomas (1981), St. Summa Theologiae, translated by Fathers of the English Dominican Province. Westminster, UK: Christian Classics.

Arndt, Johan (1981), “The Political Economy of Marketing Systems: Reviving the Institutional Approach," Journal of Macromarketing, 1 (2), 36-47.

Ballantyne, David and Richard J. Varey (2006), "Creating Value-InUse through Marketing Interaction: The Exchange Logic of Relating, Communicating and Knowing," Marketing Theory, 6 (3), 335-48.

Baumeister, Roy F. and Stephen Hastings (1997), "Distortions of Collective Memory: How Groups Flatter and Deceive Themselves," in Collective Memory of Political Events: Social Psychological Perspectives, James W. Pennebaker, Dario Paez, and Bernard Rimé, eds. Hillsdale, UK: Lawrence Erlbaum Associates, 277-93.

BBC (2012), "Apple Addresses China Foxconn Factory Report," (accessed February 1, 2014), [available at http://www.bbc.com/ news/technology17557630].

Belk, Russell W. (1988), "Possessions and the Extended Self," Journal of Consumer Research, 15 (2), 139-69.

Berger, Peter L. and Thomas Luckmann (1966), The Social Construction of Reality: A Treatise in the Sociology of Knowledge. New York: Anchor Books.

Blaug, Mark (1980), The Methodology of Economics: Or, How Economists Explain. Cambridge, UK: Cambridge University Press.

Bledstein, Burton J. and Robert D. Johnston, eds. (2001), The Middling Sorts: Explorations in the History of the American Middle Class. New York: Routledge.

Brennan, Ross, Lynne Eagle, and David Rice (2010), "Medicalization and Marketing," Journal of Macromarketing, 30 (1), 8-22.

Bulow, Jeremy (1986), “An Economic Theory of Planned Obsolescence," The Quarterly Journal of Economics, 101 (4), 729-49.

Burnett, Claire (2014), The Men Who Made us Spend [Television Series]. London: BBC.
Chamberlin, Edward (1933), Monopolistic Competition: The Theory of Monopolistic Competition. Cambridge, MA: Harvard University Press.

Crespo, Ricardo F. (2014), A Re-Assessment of Aristotle's Economic Thought (Routledge Studies in the History of Economics). New York: Routledge.

Creswell, John W. (2012), Qualitative Inquiry and Research Design: Choosing Among Five Approaches. Thousand Oaks, CA: Sage.

Daly, Herman E. and John B. Cobb (1994), For the Common Good: Redirecting the Economy Toward Community, the Environment, and a Sustainable Future. Boston: Beacon Press.

de Coverly, Edd, Pierre McDonagh, Lisa O'Malley, and Maurice Patterson (2008), "Hidden Mountain: The Social Avoidance of Waste," Journal of Macromarketing, 28 (3), 289-303.

Denzin, Norman K. and Yvonna S. Lincoln (2011), The SAGE Handbook of Qualitative Research. Thousand Oaks, CA: Sage.

Dholakia, Nikilesh (2012), “'Finanzkapital' and Consumers: How Financialization Shaped Twentieth Century Marketing," Journal of Historical Research in Marketing, 4 (3), 453-61.

Dierksmeier, Claus and Michael Pirson (2009), "Oikonomia versus Chrematistike: Learning From Aristotle about the Future Orientation of Business Management," Journal of Business Ethics, 88 (3), 417-30.

Durrenberger, Paul E. and Gisli Palsson, eds (2015), Gambling Debt: Iceland's Rise and Fall in the Global Economy. Boulder: University Press of Colorado.

Etzioni, Amitai (1988), The Moral Dimension: Toward A New Economics. New York: The Free Press.

Etzioni, Amitai (1999), Essays in Socio-Economics. Berlin: Springer.

Fisk, George (1981), "An Invitation to Participate in Affairs of the Journal of Macromarketing," Journal of Macromarketing, 1 (1), 3-6.

Fisk, George (1967), Marketing Systems: An Introductory Analysis. New York, NY: Harper and Row.

Galbraith, John K. (1958), The Affluent Society. Harmondsworth, UK: Penguin Books.

Galbraith, John K. (1975), Money: From Whence It Came, Where It Went. Boston: Houghton Mifflin.

Galbraith, John K. (2004), The Economics of Innocent Fraud: Truth for Our Time. Boston: Houghton Mifflin.

Gantt, Edwin E. and Judson Burton (2013), "Egoism, Altruism, and the Ethical Foundations of Personhood," Journal of Humanistic Psychology, 53 (4), 438-60.

Gaski, John F. (2012), “To Serve Man: A Marketing Manifesto (and an Article that Should not Have Been Necessary)," Journal of Public Policy and Marketing, 32 (1), 6-17.

Geertz, Clifford (1978), "The Bazaar Economy: Information and Search in Peasant Marketing," The American Economic Review, 68 (2), 28-32.

Gilbert, Margaret (2005), "Corporate Misbehavior and Collective Values," Brooklyn Law Review, 70 (4), 1369-80.

Granovetter, Mark (1985), "Economic Action and Social Structure: The Problem of Embeddedness," American Journal of Sociology, 91 (3), 481-510.

Granovetter, Mark (1988), "The Sociological and Economic Approaches to Labor Market Analysis," in Industries, Firms, and 
Fobs: Sociological and Economic Approaches, George Farkas and Paula England, eds. New York: Plenum Press, 187-216.

Granovetter, Mark and Richard Swedberg, eds. (1992), The Sociology of Economic Life. Philadelphia: Westview Press.

Guba, Egon G. and Yvonna S. Lincoln (2005), "Paradigmatic Controversies, Contradictions, and Emerging Confluences," in The Sage Handbook of Qualitative Research, Norman K. Denzin and Yvonna S. Lincoln, eds. Thousand Oaks, CA: Sage, 191-216.

Hastings, Gerard and Nick Sheron (2013), "Alcohol Marketing: Grooming the Next Generation," BMJ: British Medical Journal, 346 (f1227), 1-2.

Heilbroner, Robert (1985), The Nature and Logic of Capitalism. New York: W. W. Norton \& Company.

Heinberg, Richard (2011), The End of Growth: Adapting to Our New Economic Reality. Gabriola Island, Canada: New Society Publishers.

Henry, Paul, Ellen Garbarino, and Ranjit Voola (2013), "Metacognitions about Consumer Protection and Individual Responsibility in the Credit Card Domain," Journal of Public Policy and Marketing, 32 (1), 32-44.

Hill, Ronald P. and Martin, Kelly D. (2013), "Broadening the Paradigm of Marketing as Exchange: A Public Policy and Marketing Perspective," Journal of Public Policy and Marketing, 33 (1), 17-33.

Humphreys, Ashlee (2010), "Megamarketing: The Creation of Markets as a Social Process," Journal of Marketing, 74 (2), 1-19.

Hunt, Shelby D. (2011), "The Theory of Monopolistic Competition, Marketing's Intellectual History, and the Product Differentiation Versus Market Segmentation Controversy," Journal of Macromarketing, 31 (1), 73-84.

Hunt, Shelby D. and Robert M. Morgan (1995), "The Comparative Advantage Theory of Competition," Journal of Marketing, 59 (2), 1-15.

Kadirov, Djavlonbek (2011), "Macro-Systems Role of Marketing: Do we Trade Environment for Welfare?" Journal of Macromarketing, 31 (4), 359-75.

Kadirov, Djavlonbek and Richard J. Varey (2011), "Symbolism in Marketing Systems," Journal of Macromarketing, 31 (2), 160-71.

Kang, David C. (2002), Crony Capitalism: Corruption and Development in South Korea and the Philippines. Cambridge, UK: Cambridge University Press.

Kesselheim, Aaron S., Michelle M. Mello, and David M. Studdert (2011), "Strategies and Practices in Off-Label Marketing of Pharmaceuticals: A Retrospective Analysis of Whistleblower Complaints," PLoS Medicine, 8 (4), e100043.

Kilbourne, William E. (2004), "Globalization and Development: An Expanded Macromarketing View," Journal of Macromarketing, 24 (2), 122-35.

Kilbourne, William E., Michael J. Dorsch, Pierre McDonagh, Bertrand Urien, Andrea Prothero, Marko Grünhagen, Michael Polonsky, David Marshall, Janice Foley, and Alan Bradshaw (2009), "The Institutional Foundations of Materialism in Western Societies: A Conceptualization and Empirical Test," Journal of Macromarketing, 29 (3), 259-78.

Kilbourne, William E., Pierre McDonagh, and Andrea Prothero (1997), "Sustainable Consumption and the Quality of Life: A
Macromarketing Challenge to the Dominant Social Paradigm," Journal of Macromarketing, 17 (1), 4-21.

Kirchgässner, Gebhard (2014), “On Self-Interest and Greed.” Journal of Business Economics, 84 (2), 1191-1209.

Laczniak, Gene R. and Patrick E. Murphy (2006), "Normative Perspectives for Ethical and Socially Responsible Marketing," Journal of Macromarketing, 26 (2), 154-77.

Laczniak, Gene R. and Patrick E. Murphy (2008), “Distributive Justice: Pressing Questions, Emerging Directions, and the Promise of Rawlsian Analysis," Journal of Macromarketing, 28 (1), 5-11.

Laczniak, Gene R. and Patrick E. Murphy (2012), "Stakeholder Theory and Marketing: Moving from a Firm-Centric to a Societal Perspective," Journal of Public Policy and Marketing, 31 (2), 284-92.

Layton, Roger A. (2007), "Marketing Systems - A Core Macromarketing Concept," Journal of Macromarketing, 27 (3), 227-42.

Layton, Roger A. (2009), “'On Economic Growth, Marketing Systems, and the Quality of Life," Journal of Macromarketing, 29 (4), 349-62.

Layton, Roger A. and Sanford Grossbart (2006), "Macromarketing: Past, Present, and Possible Futures," Journal of Macromarketing, 26 (2), 193-213.

Lewis, Michael (2010), The Big Short: Inside the Doomsday Machine. New York: W. W. Norton and Company.

Lewis, Michael (2011), Boomerang: Travels in the New Third World. New York: W. W. Norton \& Company.

Loughran, Tim and Bill McDonald (2011), "When is a Liability Not a Liability? Textual Analysis, Dictionaries, and $10 \mathrm{Ks}$," The Journal of Finance, 66 (1), 35-65.

Loughran, Tim, Bill McDonald, and Hayong Yun (2009), “A Wolf in Sheep's Clothing: The Use of Ethics-Related Terms in $10 \mathrm{~K}$ Reports," Journal of Business Ethics, 89 (1), 39-49.

Marx, Karl (1887), Capital: A Critique of Political Economy. Moscow: Progress Publishers.

McCloskey, Deirdre N. (2006), The Bourgeois Virtues: Ethics for an Age of Commerce. Chicago: University of Chicago Press.

McCloskey, Deirdre N. (2011), Bourgeois Dignity: Why Economics Can't Explain the Modern World. Chicago: University of Chicago Press.

Ménard, Claude and Mary M. Shirley (2005), Handbook of New Institutional Economics. Dordrecht, Germany: Springer.

Mick, David G. (2007), "The End(s) of Marketing and the Neglect of Moral Responsibility by the American Marketing Association," Journal of Public Policy and Marketing, 26 (2), 289-92.

Mittelstaedt, John D., William E. Kilbourne, and Robert A. Mittelstaedt (2006), "Macromarketing as Agorology: Macromarketing Theory and the Study of the Agora," Journal of Macromarketing, 26 (2), 131-42.

Morgenson, Gretchen and Joshua Rosner (2011), Reckless Endangerment: How Outsized Ambition, Greed and Corruption Led to Economic Armageddon. New York: Times Books.

Moses, Jonathon W. and Torbjorn L. Knutsen (2007), Ways of Knowing: Competing Methodologies in Social and Political Research. New York: Palgrave Macmillan.

North, Douglass C. (1981), Structure and Change in Economic History. New York: W. W. Norton \& Company. 
North, Douglass C. (1989), "Final Remarks: Institutional Change and Economic History," Journal of Institutional and Theoretical Economics, 145 (1), 238-45.

Patsiaouras, Georgios, Michael Saren, and James A. Fitchett (2015), "The Marketplace of Life? An Exploratory Study of the Commercialization of Water Resources through the Lens of Macromarketing," Journal of Macromarketing, 35 (1), 23-35.

Piketty, Thomas (2014), Capital in the 21st Century, Cambridge, MA: Harvard University Press.

Polanyi, Karl (1944), The Great Transformation: The Political and Economic Origins of Our Time. Boston: Beacon Press.

Redmond, William H. (2005), "Intrusive Promotion as Market Failure: How Should Society Impact Marketing?" Journal of Macromarketing, 25 (1), 12-21.

Redmond, William H. (2009), “A Political Economy of Regulatory Failure in US Packaged Food Markets," Journal of Macromarketing, 29 (2), 135-44.

Redmond, William H. (2012), "Strategic Foreclosure as an Indicator of Eroding Institutional Structures," Journal of Economic Issues, 46 (2), 565-72.

Redmond, William H. (2013), "A Marketing Systems View of the US Housing Crisis," Journal of Macromarketing, 33 (2), 117-27.

Schwartz, Barry (1986), The Battle for Human Nature. New York: W. W. Norton \& Company.

Sen, Amartya (1977), "Rational Fools: A Critique of the Behavioural Foundations of Economic Theory," Philosophy and Public Affairs, 6 (4), 317-44.

Sen, Amartya (1993), "Markets and Freedoms: Achievements and Limitations of the Market Mechanism in Promoting Individual Freedoms," Oxford Economic Papers, 45 (4), 519-41.

Sheth, Jagdish N. and Rajendra S. Sisodia (2006), Does Marketing Need Reform? Fresh Perspectives on the Future. Armonk, NY: M.E. Sharpe.

Shultz, II, Clifford J. and Morris B. Holbrook (1999), "Marketing and the Tragedy of the Commons: A Synthesis, Commentary, and Analysis for Action," Journal of Public Policy \& Marketing, 18 (2), 218-30.

Slade, Giles (2009), Made to Break: Technology and Obsolescence in America. Cambridge, MA: Harvard University Press.

Stewart, Ross E. (1984), “Sismondi's Forgotten Ethical Critique of Early Capitalism," Journal of Business Ethics, 3 (3), 227-34.

Stiglitz, Joseph E. (1991), "The Invisible Hand and Modern Welfare Economics," National Bureau of Economic Research, (accessed February 3, 2014), [available at http://www.nber.org/papers/ w3641].

Stiglitz, Joseph E. (2002), Globalization and its Discontents. New York: Norton.

Stiglitz, Joseph E. (2010), Freefall: America, Free Markets, and the Sinking of the World Economy. New York: W. W. Norton \& Company.

The Telegraph (2012), "Mass Suicide Protest at Apple Manufacturer Foxconn Factory," (accessed February 10, 2014), [available at http://www.telegraph.co.uk/news/worldnews/asia/china/9006988/ Mass-suicide-protest-at-Apple-manufacturer-Foxconn-factory].
Urban, Glen L. (2005), "Customer Advocacy: A New Era in Marketing?" Journal of Public Policy and Marketing, 24 (1), 155-59.

Varey, Richard J. (2010), "Marketing Means and Ends for a Sustainable Society: A Welfare Agenda for Transformative Change," Journal of Macromarketing, 30 (2), 112-26.

Varman, Rohit and Janeen Arnold Costa (2008), "Embedded Markets, Communities, and the Invisible Hand of Social Norms," Journal of Macromarketing, 28 (2), 141-56.

Waldman, Michael (1993), "A New Perspective on Planned Obsolescence," The Quarterly Journal of Economics, 108 (1), 273-83.

Wallerstein, Immanuel (1987), “The Bourgeois(ie) as Concept and Reality," (accessed May 29, 2015), [available http://newleftreview.org/static/assets/archive/pdf/NLR16305.pdf].

Wallerstein, Immanuel (2011). The Modern World-System III: The Second Era of Great Expansion of the Capitalist WorldEconomy, 1730s-1840s. Berkeley, CA: University of California Press.

Weber, Max (1978), Economy and Society: An Outline of Interpretive Sociology. Berkeley: University of California Press.

Williamson, Oliver E. (1993), "Opportunism and its Critics," Managerial and Decision Economics, 14 (2), 97-107.

Williamson, Oliver E. (1985), The Economic Institutions of Capitalism. New York: Free Press.

\section{Author Biographies}

Djavlonbek Kadirov ( $\mathrm{PhD}$, University of Waikato) is a Marketing Lecturer at the School of Marketing and International Business, Victoria University of Wellington, New Zealand. Djavlonbek's research interests include marketing systems, marketing and society, sustainable marketing/consumption, and marketing ethics. His research has appeared in journals such as the Journal of Macromarketing, Journal of Marketing Management, Journal of Business Research, Consumption Markets \& Culture, and Journal of Customer Behaviour. Djavlonbek (along with Richard Varey and Ben Wooliscroft) is the winner of the George Fisk Award for the Best Conference Paper at the 2013 Macromarketing Conference.

Richard J. Varey (PhD, UMIST) is currently a visiting Professor at the University of Otago, Dunedin, New Zealand. His scholarship has focused on the impact of commercial marketing, on social marketing, on interaction in market situations, and on systems of managed communication.

Sally Wolfenden brought a wealth of marketing experience to her role as a former Marketing Lecturer at the Eastern Institute of Technology (New Zealand), starting in the leisure industry, progressing to marketing agencies and then into media publishing. She is now studying full-time at Bournemouth University for a $\mathrm{PhD}$ in the field of digital marketing, building on her MBA from the University of Glasgow, her work at the UK's leading media publisher Associated Newspapers Ltd and marketing experience encompassing direct, database, digital, online marketing and customer relationship management. 